\title{
Molecular and Biological Characterization of Tomato chlorotic mottle virus Suggests that Recombination Underlies the Evolution and Diversity of Brazilian Tomato Begomoviruses
}

\author{
Simone G. Ribeiro, Darren P. Martin, Cristiano Lacorte, Isabella C. Simões, \\ Deborah R. S. Orlandini, and Alice K. Inoue-Nagata
}

First, third, fourth, and fifth authors: Embrapa Recursos Genéticos e Biotecnologia, Parque Estação Biológica, CEP 707770-900, Brasília, DF, Brazil; first and third authors: Laboratory of Virology, Wageningen University, Wageningen, The Netherlands; second author: Institute of Infectious Diseases and Molecular Medicine, University of Cape Town, Observatory, Cape Town, 7925, South Africa; and sixth author: Embrapa Hortaliças Cx. Postal 218, CEP 70359-970, Brasília, DF, Brazil.

Accepted for publication 26 November 2006.

\begin{abstract}
Ribeiro, S. G., Martin, D. P., Lacorte, C., Simões, I. C., Orlandini, D. R. S., and Inoue-Nagata, A. K. 2007. Molecular and biological characterization of Tomato chlorotic mottle virus suggests that recombination underlies the evolution and diversity of Brazilian tomato begomoviruses. Phytopathology 97:702-711.

Tomato chlorotic mottle virus (ToCMoV) is an emerging begomovirus species widely distributed throughout tomato-growing regions of Brazil. ToCMoV appears to have expanded its geographic range recently, invading tomato-growing areas that were free of begomovirus infection before 2004. We have determined the first complete genome sequence of an infectious ToCMoV genome (isolate BA-Se1), which is the first

by particle bombardment into tomato, the cloned ToCMoV-[BA-Se1] DNA-A and DNA-B components caused typical chlorotic mottle symptoms. The cloned virus was whitefly-transmissible and, although it was infectious in hosts such as Nicotiana benthamiana, pepper, tobacco, and Nicandra physaloides, it was unable to infect Arabidopsis thaliana, bean, $N$. glutinosa, and Datura metel. Sequence and biological analyses indicate that ToCMoV-[BA-Se1] is a typical New World begomovirus sp. requiring both DNA-A and DNA-B components to establish systemic infections. Although evidence of multiple recombination events was detected within the ToCMoV-[BA-Se1] DNA-A, they apparently occurred relatively long ago, implying that recombination probably has not contributed to the recent emergence of this species.
\end{abstract} begomovirus species isolated in the northeast of Brazil. When introduced
The genus Begomovirus contains geminiviruses that infect dicotyledonous plants and are transmitted by the whitefly Bemisia tabaci Gannadius. Begomoviruses have emerged everywhere in the world where environmental conditions support large $B$. tabaci populations, and have become a major constraint in the production of food and fiber crops such as cassava, tomato, cucurbits, pepper, bean, and cotton $(34,51)$.

Begomoviruses indigenous to the Western hemisphere (i.e., New World begomoviruses) have bipartite genomes with components referred to as DNA-A and DNA-B. DNA-A encodes genes responsible for viral replication, regulation of gene expression, suppression of gene silencing, and particle encapsidation. DNA-B encodes proteins involved in virus movement, host range determination, and symptom development $(25,45)$.

In the Americas, the vegetable crop currently suffering most seriously from begomovirus infection is tomato. Epidemics that can result in up to $100 \%$ yield losses are often observed, resulting in severe economic and social consequences $(9,34,37,51)$. Although tomato is the most common host from which New World begomoviruses have been isolated $(12,51)$, there is no reason to suppose that all begomovirus species threatening tomato have yet been sampled. Considering the current rate at which new bego-

Corresponding author: S. G. Ribeiro;

E-mail address: simone@ cenargen.embrapa.br

doi:10.1094/PHYTO-97-6-0702

(C) 2007 The American Phytopathological Society movirus species are being discovered, it is probable that many more undescribed species are yet to emerge as a threat to tomato and other crop cultivation in the Americas.

Before the 1990s, the only known begomovirus disease of tomato in Brazil was caused by Tomato golden mosaic virus (TGMV). However, the introduction and rapid spread of a new $B$. tabaci biotype (referred to as biotype B) throughout Brazil in the mid-1990s has corresponded to a massive increase in the prevalence and severity of tomato-infecting begomoviruses, and associated disease problems in tomato have escalated to epidemic proportions $(9,40)$. Partial sequence characterization of begomoviruses collected in the main tomato-producing areas of Brazil during these outbreaks has revealed that they have an extraordinarily high degree of genetic diversity, with at least nine new emergent species believed to be present in the country $(1,9,39)$. Although there is ample information available on TGMV, very little is known about the other recently discovered tomato-infecting begomovirus species.

One of these new species is Tomato chlorotic mottle virus (ToCMoV). Although ToCMoV was the first begomovirus specie isolated in the northeastern region of Brazil $(9,39)$, it appears to be widely distributed and is also present in several states in the southeastern region of the country $(1,39)$. The DNA-A component of a ToCMoV isolate $\mathrm{Mg}-\mathrm{Bt} 1$ from the southeastern state of Minas Gerais previously was isolated and reported to systemically infect Nicotiana benthamiana plants, but not tomato, its natural host (16). This article reports the biological characterization, cloning, and sequencing of the complete ToCMoV-[BA-Se] 
genome. Extensive sequence comparisons with other New World begomoviruses were performed to elucidate the role of recombination in the emergence of these viruses.

\section{MATERIALS AND METHODS}

Virus isolate. In 1996, tomato leaf samples with yellow mottle symptoms were collected in Seabra, Bahia, Brazil. Total DNA was isolated from the infected leaves (7) and evaluated for the presence of begomoviruses by polymerase chain reaction (PCR) using the degenerate primer pair PAL1v1978 and PAR1c715 for DNA-A and CRC2, and PBL1v2040 for DNA-B (44). For propagation of the isolate, total DNA was precipitated onto tungsten particles and delivered to healthy seedlings of $N$. benthamiana by particle bombardment (2).

Cloning and sequencing of the viral genome. Total DNA was isolated from $N$. benthamiana-infected leaf, digested with several restriction enzymes, and analyzed by Southern blot using DNA-A and DNA-B PCR fragments (labeled by random priming with ${ }^{32} \mathrm{P}$ ) as probes to identify the enzymes with single cutting sites in each component. From this analysis, KpnI and HindIII appeared to linearize DNA-A and DNA-B, respectively. Hence, these enzymes were used to digest total DNA. KpnI- and HindIII-digested DNA was fractionated in an agarose gel and fragments ranging from 2.0 to $3.0 \mathrm{~kb}$ were excised from the gel and ligated into either KpnIor HindIII-digested pBS KS+ (Stratagene, La Jolla, CA). Recombinant clones were identified by colony hybridization with DNA-A or DNA-B probes. Two full-length DNA-A and DNA-B clones were sequenced. Sequence analysis and comparesons were performed using the open reading frame (ORF) finder and BLAST web servers and DNAMAN version 4.0 (Lynnon Biosoft, Québec).

Infectivity of cloned ToCMoV-[BA-Se1] genome components. To test the infectivity of cloned ToCMoV-[BA-Se1] genome components, DNA-A and DNA-B were cut from their vector with KpnI or HindIII, respectively, and self-ligated to form closed, circular double-stranded DNA molecules. In all, $\approx 2.5$ to $5 \mu \mathrm{g}$ of each component was precipitated onto tungsten particles and inoculated by particle bombardment into Lycopersicon esculentum 'Viradoro' seedlings. Plants bombarded only with pBS KS+ were included as negative controls. Plants were monitored for symptom development and infection was confirmed by squash blot hybridization using probes specific for ToCMoV-[BA-Se1] DNA-A and DNA-B.

Whitefly transmission. To test whether the progeny of cloned ToCMoV-[BA-Se1] components were whitefly transmissible, symptomatic tomato plants inoculated by particle bombardment were used in transmission experiments. Individuals of $\mathrm{B}$. tabaci biotype $\mathrm{B}$ were reared on squash plants, transferred to an infected tomato plant, and allowed an acquisition access period of $48 \mathrm{~h}$. Five adult flies subsequently were transferred to a clip cage and placed in contact with the abaxial leaf surface of a healthy tomato plant for an inoculation access period of $48 \mathrm{~h}$. Two cages were placed on each test plant. The plants were observed for symptom development and analyzed for the presence of virus by squash hybridization.

Experimental host range of ToCMoV-[BA-Se1]. During host range experiments with $\mathrm{ToCMoV}-[\mathrm{BA}-\mathrm{Se} 1]$, we inoculated potential hosts both mechanically and by particle bombardment. Seedlings of L. esculentum ('Santa Clara' and 'Viradoro'), $N$. tabacum ('TNN'), N. benthamiana, Nicandra physaloides, Datura stramonium, D. metel, Capsicum annuum ('Margarita' and 'AG10'), and Glycine max ('Celeste' and 'Conquista') were inoculated by particle bombardment as described above. Mechanical inoculations were conducted by grinding Nicotiana benthamiana-infected leaf tissue in phosphate buffer, $\mathrm{pH} 8.0$, containing $25 \mathrm{mM}$ EDTA and $0.01 \%$ sodium sulfite, and rubbing the extract onto carborundum-dusted leaves of Arabidopsis thaliana var. Columbia, L. esculentum ('Money Maker' and 'Tiny Tim'), $C$. annuum ('Pikante Reuzen'), N. tabacum ('White Burley'), $N$. rustica, $N$. rosellata, $N$. clevelandii, $N$. benthamiana, D. stramonium, Petunia hybrida, and Phaseolus vulgaris ('Olathe Pinto'). Mock-inoculated plants were used as negative controls. Plants were monitored and scored for symptoms. Virus infection was confirmed by squash blot or PCR using degenerated primers.

Reassortment experiments. To test whether ToCMoV-[BASe1] and the closely related virus Tomato rugose mosaic virus (ToRMV) (13) were able to form viable pseudorecombinants, infectious DNA-A and DNA-B clones of both viruses were mixed and inoculated, in all possible combinations, into $N$. benthamiana seedlings by particle bombardment. Results were scored by visual observation of symptom development and by squash blot using virus-specific probes.

Phylogenetic analysis. Multiple alignments of complete New World Begomovirus DNA-A and DNA-B components were prepared using ClustalX (49). Phylogenetic trees were constructed using the maximum parsimony method implemented in PAUP version 4.0b10 (Swofford, D. L., Sinauer Assoc., Sunderland, MA). The most parsimonious tree was searched for using the heuristic method with stepwise addition and the tree bisection-reconnection branch-swapping options. Bootstrap analysis was performed using 1,000 replicates. Tomato yellow leaf curl virus-[Dominican Republic] (TYLCV-[DO]) and African cassava mosaic virus-[Cameroon] (ACMV-[CM]) were used as outgroups for DNA-A and DNA-B phylogenetic trees, respectively.

Recombination analysis. An alignment of 55 New World Begomovirus DNA-A sequences was analyzed for recombination events involving either of the two ToCMoV isolates, BA-Se1 and MG-Bt1, using the rdp (30), Geneconv (35), Bootscan (29), maximum $\chi^{2}$ (32), Chimaera (31), and sister scan (17) detection methods as implemented in RDP2 (31). A multiple comparison corrected $P$ value cutoff of 0.05 and default settings were used throughout, and only events detectable by two or more different methods were retained for further analysis. For each event involving either of the two ToCMoV isolates as donor or acceptor sequences, two neighbor-joining trees were constructed, using portions of the alignment bounded by the two detected recombination breakpoints. The minimum number of branch transplants needed to convert the tree topology of one tree into that of the other was used to infer which of the sequences used to detect recombination events were donors or acceptors (33). In the case of ties between two sequences, a distance-based measurement based on that used in the Phylpro method (52) was used as a tiebreaker. Both methods are implemented in the $\beta$ version of RDP3, which is available on request from D. P. Martin. An alignment of 33 New World Begomovirus DNA-B sequences was examined for evidence of recombination events involving ToCMoV-[BA-Se1] in a manner identical to that described for the DNA-A sequences.

The following Begomovirus sequences were obtained from the GenBank and used for phylogenetic comparisons and recombinetion analysis: Abutilon mosaic virus (AbMV: X15983, X15984); Abutilon mosaic virus-HW (AbMV-HW: U51137, U51138); African cassava mosaic virus-[Cameroon] (ACMV-[CM]: AF112353); Bean calico mosaic virus (BCaMV: AF110189, AF110190); Bean dwarf mosaic virus (BDMV: M88179, M88180); Bean golden mosaic virus-[Brazil] (BGMV-[BR]: M88686, M88687); Bean golden yellow mosaic virus-[Dominican Republic] (BGYMV-[DO]: L01635. L01636); Bean golden yellow mosaic virus-[Guatemala] (BGYMV[GT]: M91604, M91605); Bean golden yellow mosaic virus[Mexico] (BGYMV-[MX]: AF173555, AF173556); Bean golden yellow mosaic virus-[Puerto Rico] (BGYMV-[PR]: M10070, M10080); Cabbage leaf curl virus (CaLCuV: U65529, U65530); Chino del tomate virus-[H6] (CdTV-[H6]: AF226665); Chino del tomate virus-[H8] (CdTV-[H8]: AF226664); Chino del tomate virus-[IC] (CdTV-[IC]: AF101476, AF101472); Cotton leaf crumple virus (CLCrV: AF480940); Cucurbit leaf curl virus (CuLCuV: 
AF224760, AF224761); Cucurbit leaf curl virus-[Arizona] (CuLCuV-[AZ]: AF256200, AF327556); Dicliptera yellow mottle virus (DiYMV: AF139168, AF170101); Macroptilium mosaic Puerto Rico virus (MaMPRV: AY044133, AY044134); Macroptilium yellow mosaic Florida virus (MaYMFV: AY044135, AY044136); Macroptilium yellow mosaic virus (MaYMV: AJ344452); Melon chlorotic leaf curl virus (MCLCuV: AF325497); Nicandra deforming necrosis virus (NDNV: unpublished); Pepper huasteco yellow vein virus (PHYVV: X70418, X70419); Potato yellow mosaic Panama virus (PYMPV: Y15034, Y15033); Potato yellow mosaic Trinidad virus (PYMTV: AF039031, AF039032); Potato yellow mosaic virus-[Venezuela] (PYMV-[VE]: D00940, D00941); Potato yellow mosaic virus[Guadalupe] (PYMV-[GP]: AY120882); Rhynchosia golden mosaic virus (RhGMV: AF239671); Sida golden mosaic Costa Rica virus (SiGMCRV: X99550, X99551); Sida golden mosaic Honduras virus (SiGMHV: Y11097, Y11098); Sida golden mosaic virus (SiGMV: AF049336, AF039841); Sida micrantha mosaic virus-[A1B3] (SimMV-[A1B3]: AJ557450, AJ557454); Sida micrantha mosaic virus-[A2B2] (SimMV-[A2B2]: AJ557451, AJ557453); Sida mottle virus (SiMoV: AY090555); Sida yellow mosaic virus (SiYMV: AY090558); Sida yellow vein virus (SiYVV: Y11099, Y11100); Squash leaf curl virus (SLCV: M38183, M38182); Squash mild leaf curl virus (SMLCV: AF421552, AF421553); Squash yellow mild mottle virus-[Costa
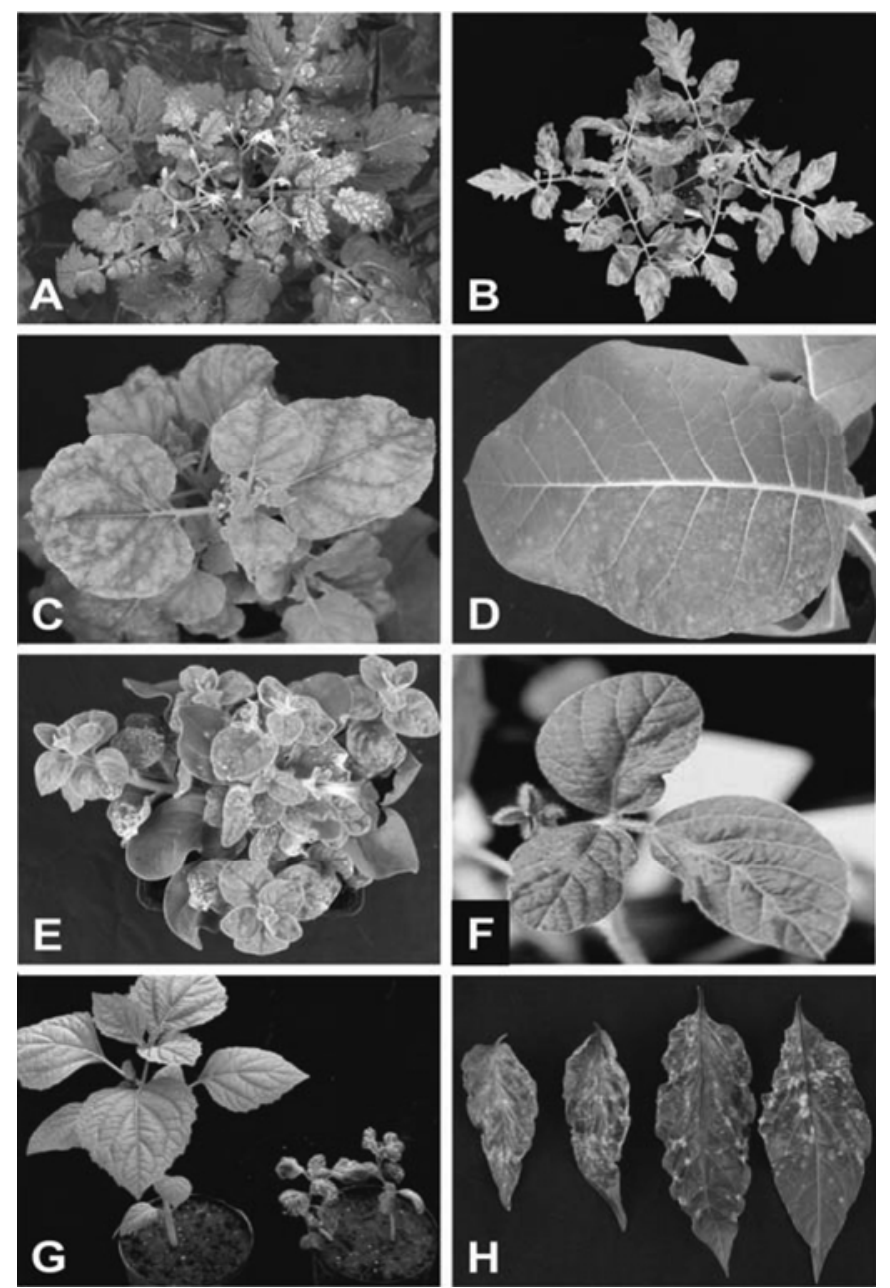

Fig. 1. Symptoms induced by Tomato chlorotic mottle virus-[BA-Se1]. A, Tomato 'Tiny Tim' and B, 'Viradoro' showing typical yellow mottle. C, Mottling in Nicotiana benthamiana; D, tobacco 'White Burley'; E, petunia; and F, soybean 'Celeste'. G, Nicandra physaloides showing mosaic, leaf deformation, and severe stunting. H, Chlorotic spots and leaf deformation in pepper 'Pikante Reuzen.'
Rica] (SYMMoV-[CR]: AY064391, AF440790); Sweet potato leaf curl Georgia virus (SPLCGV: AF326775); Sweet potato leaf curl virus (SPLCV: AF104036), ToCMoV-[BA-Se1] (AF490004, AF491306), ToCMoV-[MG-Bt-1] (AY090557); Tomato crinkle leaf yellow virus (ToCrLYV: AY090556); Tomato golden mosaic virus-[Yellow vein] (TGMV-[YV]: K02029, K02030); Tomato mosaic Havana virus-[Quivican] (ToMHV-[Qui]: Y14874, Y14875); Tomato mosaic leaf curl virus (ToMLCV: AY508991); Tomato mottle Taino virus (ToMoTV: AF012300, AF012301); Tomato mottle virus-[Florida] (ToMoV-[FL]: L14460, L14461), ToRMV (AF291705, AF291706); Tomato severe leaf curl virus[Guatemala 96-1] (ToSLCV-[GT96-1]: AF130415); Tomato severe rugose virus (ToSRV: AY029750); Tomato yellow margin leaf curl virus (ToYMLCV: AY508993); and Tomato yellow leaf curl virus-[Dominican Republic] (TYLCV-[DO]: AF024715).

\section{RESULTS}

Cloning and infectivity of cloned viral components. Begomovirus infections initially were detected in field-infected tomato plants collected in Seabra, Bahia, Brazil, by PCR using degenerate primers (39). Several potentially full-length clones $(\approx 2,600$ nucleotides [nt]) were obtained from $N$. benthamiana infected with DNA extracted from diseased tomato, and identified as DNA-A or DNA-B by Southern hybridization. Two clones representing DNA-A (pK56 and pK133) and two DNA-B clones ( $\mathrm{pH} 81$ and $\mathrm{pH} 2$ ) were chosen for infectivity tests. Clone pK56 shared $99 \%$ nucleotide identity with $\mathrm{pK} 133$, and $\mathrm{pH} 81$ shared $99 \%$ identity with $\mathrm{pH} 2$. At $\approx 14$ days post inoculation (dpi), tomato 'Viradoro' seedlings that had been bombarded with all combinations of cloned DNA-A and DNA-B components developed symptoms of vein chlorosis, chlorotic spots, and yellow mottle, similar to symptomatic tomato plants observed in the field (Fig. 1B). Systemic infection was confirmed by squash blot analysis of newly emerged symptomatic leaves using both DNA-A and DNA$B$ probes. None of the plants inoculated either with DNA-A, DNA-B, or pBS KS+ alone developed symptoms, and no virus was detectable by squash blot analysis. All combinations of DNA$A$ and DNA-B were infectious and induced indistinguishable symptoms in tomato plants; therefore, clones pK56 and pH81 were chosen as representative of ToCMoV-[BA-Se1] DNA-A and DNA$\mathrm{B}$ components, respectively, and were used throughout this study.

Host range and whitefly transmission. ToCMoV-[BA-Se1] could infect a range of different host species when inoculated either by particle bombardment with cloned DNA-A and DNA-B or by mechanical inoculation using infected $N$. benthamiana as the inoculum source (Table 1; Fig. 1). All inoculated tomato cultivars displayed chlorotic spots, vein chlorosis, and typical yellow mottling $\approx 14 \mathrm{dpi}$, regardless of the inoculation procedure (Fig. 1A and B). Infected N. benthamiana plants were stunted and developed vein clearing, crumpling, epinasty, and systemic mottling (Fig. 1C). However, no symptoms were observed and viral DNA was undetectable when either plant species was bombarded with only ToCMoV-[BA-Se1] DNA-A or DNA-B alone. This demonstrates again the requirement of both components for the establishment of a systemic infection. Tobacco plants 'TNN' and 'White Burley' presented systemic mottling (Fig. 1D) and Petunia hybrida exhibited vein chlorosis, chlorotic spots, and chlorotic mottle (Fig. 1E). Pepper cultivars displayed chlorotic spots and leaf deformation (Fig. 1H). In the weed Nicandra physaloides, ToCMoV-[BA-Se1] caused mosaic, leaf deformation, and very severe stunting (Fig. 1G). Only one soybean plant from 'Celeste' became infected and showed vein chlorosis, chlorotic spots, leaf mottle, and deformation (Fig. 1F). Although virus could be detected in all symptomatic plants by either squash blot or PCR, mock-inoculated control plants always gave negative detection results. Although the virus did not spread systemically in $D$. 
stramonium, it could be detected by PCR within localized chlorotic spots at the site of inoculation. One of four inoculated Nicotiana clevelandii and $N$. rustica plants developed a systemic asymptomatic infection. Neither symptomatic nor asymptomatic infections (as determined by negative squash blot and PCR results) were observed in $G$. max 'Conquista', D. metel, $N$. rosellata, N. glutinosa, Phaseolus vulgaris 'Olathe Pinto,' and A. thaliana var. Columbia.

ToCMoV-[BA-Se1] was whitefly transmissible, and whiteflyinoculated tomato plants developed typical mottle symptoms $\approx 2$ weeks after inoculation. Ten whiteflies per plant were sufficient to achieve $100 \%$ transmission.

Genome organization. The ToCMoV-[BA-Se1] DNA-A and DNA-B components are 2,622 and 2,573 nt in length, respectively. The genomic organization of these components was characteristic of New World begomoviruses. DNA-A potentially possesses the virion-sense gene (AV1) and four complementarysense genes (AC1, AC2, AC3, and AC4) that are common to all New World begomoviruses. An additional large complementarysense ORF (AC5) between nucleotide positions 849 and 97 (overlapping with AV1), potentially encoding a 250-amino-acid protein also was present. DNA-B potentially possesses the two genes, one virion-sense (BV1) and one complementary-sense (BC1), characteristic of the DNA-B components of all bipartite begomoviruses. In both components, the virion and complementary-strand ORFs are separated by an intergenic region. Within this region, ToCMoV-[BA-Se1] DNA-A and DNA-B components share a 225 -nt common region (CR) with $98 \%$ sequence identity, indicating that the two components are very likely the cognate pair of the same begomovirus specie. The CR contains a hairpin structure with the characteristic geminiviral nonanucleotide sequence TAATATT $\downarrow$ AC in the loop at the expected origin of virion strand DNA replication $(19,24)$. A direct repeat "iteron" sequence GGGGACTGGGGT, the presumed Rep (AC1 protein product)binding site $(3,15)$, is located just upstream of a TATA box that is potentially involved in complementary-sense gene transcription. A third repeat of this iteron is located $27 \mathrm{nt}$ downstream from the AC1 initiation codon (Fig. 2).
Phylogenetic analysis. A BLASTn search of public databases indicated that the cloned DNA-A of ToCMoV-[BA-Se1] shared the greatest identities with New World begomoviruses, and was particularly similar to various other Brazilian begomoviruses. A maximum parsimony tree constructed using a multiple alignment of 48 New World begomovirus DNA-A sequences (Fig. 3) indicated that ToCMoV-[BA-Se1] and ToCMoV-[MG-Bt1] are sister taxa in a group of crop-infecting viruses within a larger Brazilian cluster of viruses. They share $92 \%$ overall identity in the DNA-A component and, in accordance with the ICTV guidelines for species demarcation in the family Geminiviridae (11), they should be regarded, therefore, as isolates or strains of the same new begomovirus specie, ToCMoV. ToCMoV-[BA-Se1] also is closely related to ToRMV and ToSRV.

Although fewer DNA-B sequences are available, phylogenetic analysis of this component also placed most of the Brazilian begomoviruses within a distinct cluster (Fig. 3). However, the division of crop- and weed-infecting viruses was not as clearly defined as it was for the DNA-A component. ToCMoV-[BA-Se1] DNA-B was more closely related to ToCrLYV and BGMV-[BR], whereas ToRMV was more closely related to a group of viruses isolated from Sida spp. (SiYMV, SiMoV, SimMV-[A1-B3], and SimMV-[A2-B2]).

Detailed nucleotide and deduced amino acid sequence comparisons between ToCMoV-[BA-Se1] and all available Brazilian begomovirus sequences are presented in Table 2. For DNA-A, the AV1 ORF was the most conserved among Brazilian begomoviruses in both nucleotide and deduced amino acid sequence. The similarity in amino acid sequence ranged from $84 \%$ with SiYMV to $99 \%$ with ToRMV. The least-conserved ORF was AC4, showing the greatest amino acid identity with ToCMoV[MG-Bt1] (86\%) and the least with NDNV (30\%). As expected, ToCMoV-[BA-Se1] generally shared the greatest degree of identity with ToCMoV-[MG-Bt1], as their AV1, AC1, AC2, and AC3 nucleotide and putative amino acid sequences were $>90 \%$ identical. Despite nucleotide sequence identities in excess of $90 \%$ for the AC4 and AC5 ORFs, amino acid identities for these ORFs were 86 and $76 \%$, respectively. Although the ToCMoV-[BA-Se1]

TABLE 1. Experimental host range and symptoms displayed by test species inoculated by particle bombardment and mechanically with Tomato chlorotic mottle virus-[BA-Se1]

\begin{tabular}{lcc}
\hline Host plant & Infectivity $^{\mathrm{a}}$ & Symptoms $^{\mathrm{b}}$ \\
\hline Biolistic inoculation & & \\
Nicotiana benthamiana & $9 / 10$ & $\mathrm{E}, \mathrm{VC}, \mathrm{Cr}, \mathrm{Mo}$ \\
N. tabacum 'TNN' & $10 / 11$ & $\mathrm{Mo}$ \\
Capsicum annuum 'Margarita' & $4 / 7$ & $\mathrm{CS}$ \\
C. annuum 'AG 10' & $9 / 12$ & $\mathrm{CS}$ \\
Glycine max 'Conquista' & $0 / 7$ & $\ldots$ \\
G. max 'Celeste' & $1 / 11$ & $\mathrm{VC}, \mathrm{CS}, \mathrm{LD}, \mathrm{Mo}$ \\
Datura metel & $0 / 9$ & $\ldots$ \\
Lycopersicon esculentum 'Viradoro' & $8 / 8$ & $\mathrm{VC}, \mathrm{Mo}, \mathrm{CS}$ \\
L. esculentum 'Santa Clara' & $8 / 9$ & $\mathrm{VC}, \mathrm{Mo}, \mathrm{CS}$ \\
Nicandra physaloides & $5 / 6$ & $\mathrm{M}, \mathrm{LD}, \mathrm{St}$, \\
Sap inoculation & & \\
L. esculentum 'Money Maker' & $5 / 5$ & $\mathrm{VC}, \mathrm{Mo}, \mathrm{Cr}, \mathrm{CS}$ \\
L. esculentum 'Tiny Tim' & $6 / 6$ & $\mathrm{VC}, \mathrm{Mo}, \mathrm{CS}$ \\
C. annuum 'Pikante Reuzen' & $6 / 6$ & $\mathrm{CS}, \mathrm{LD}$ \\
Nicotiana tabacum 'White Burley' & $5 / 5$ & $\mathrm{Mo}$ \\
N. rustica & $1 / 4$ & $\ldots$ \\
N. rosellata & $0 / 4$ & $\ldots$ \\
N. clevelandii & $1 / 4$ & $\ldots$ \\
N. benthamiana & $20 / 20$ & $\mathrm{Cr}, \mathrm{E}, \mathrm{VC}, \mathrm{Mo}, \mathrm{St}$ \\
N. glutinosa & $0 / 5$ & $\ldots$ \\
Datura stramonium & $5 / 5$ & $\mathrm{LCS}$ \\
Petunia hybrida & $8 / 8$ & $\mathrm{CS}, \mathrm{VC}, \mathrm{Mo}$ \\
Phaseolus vulgaris 'Olathe Pinto' & $0 / 5$ & $\ldots$ \\
Arabidopsis thaliana var. Columbia & $0 / 19$ & $\ldots$ \\
\hline
\end{tabular}

${ }^{a}$ Number of plants with symptoms or positive detection of infection by squash blot or polymerase chain reaction per number of plants inoculated.

${ }^{\mathrm{b}} \mathrm{CS}=$ chlorotic spots; $\mathrm{Cr}=$ crumpling; $\mathrm{E}=$ epinasty; $\mathrm{LCS}=$ local chlorotic spots; $\mathrm{LD}=$ leaf deformation; $\mathrm{M}=$ mosaic; $\mathrm{Mo}=$ mottle; VC = veinal chlorosis; and $\mathrm{St}=$ stunting. 
and ToRMV AV1, AC2, and AC3 sequences share $>90 \%$ nucleotide and deduced amino acid sequence identity, their $\mathrm{AC} 1$ and AC4 sequences share only 77 and $71 \%$ nucleotide sequence identity and 80 and $43 \%$ deduced amino acid sequence identity, respectively.

The DNA-B nucleotide sequence of ToCMoV-[BA-Se1] is most similar to that of ToCrLYV, with which it shares $76 \%$ identity. The amino acid identities of deduced BV1 and BC1 protein products of ToCMoV-[BA-Se1] and ToCrLYV were 81 and $91 \%$, respectively.
Analysis of the common region and reassortment experiments. The common region identities of all described cognate Brazilian begomovirus DNA-A/DNA-B pairs are $>93 \%$. For this reason, in the multiple alignment of CRs depicted in Figure 2 (with the exception of ToCrLYV, for which only the DNA-B sequence is available), only DNA-A CR sequences are considered. In this region, all cis-acting elements involved in viral DNA replication and transcription of the AC1 ORF are present (Fig. 2). The sequence and number of inverted and direct repeats vary among different viruses. ToCMoV-[BA-Se1], ToCMoV-[MG-

ToCMoV-[BA-Se1] : ATTTGTAATAATAGCTGGG--CACCGATTGGGGACTCTCTAAAACT--CTAAAToCMoV-[MG-Bt1] : ATTTGTAATAATAGTTGGG--CACCGATTGGGGACTCTCTAAACTTG-CTCTASimMV-[A2B2] : TTTTGTAATTAAGGG-GTGTACCCCAATTGAGAGCTCGCTCTATAAG-TCATASiYMV

BGMV

TOCrLYV-B

SimMV- [A1B3]

SiMV

NDNV

TGMV

TORMV

: ATTTGCAGAAATG-----------AACTGGGGTCTCGGCAACTCTG-TGATA-

: ACTTGTAAATAAGAGGGTGTACCCCGATTGAGCTCTCGTTCAAAAGT-CTCTA-

: TCTTGTAAATAAAGGGGTGT-CACCAATTGGGGTCTCGCTCAAACTC-CGCTAG

: TTTTGTAAATAAGGCTGTGTACTCCGGATGAGAGCTCGCTCAATAAGTCTCTAT

: TTTTGTAAATAAGGCTG-GTACTCCGGTTGAGAGCTCGCTCA-TAAGTCTCTAT

: TTTGGTAAATAAGGGAGTGT-CTCCAATTGAGCTCCTCTCAAACTTG-CGATA-

: TTTTGTAATTAAGAGGCTTACTACCAATTGAGG-AGGGGCTCCAAAAG-TTATA

TOSRV

: ATTTGTAAATATGACCCTTACTACCAATTGGTAGCT-GCTCTAAAAC-TCATA-

: ATtTGtAAATATGGCCCTTACTACCAATtGgtAGCT-GCTCTAAAAC-TCATA-

ToCMoV-[BA-Se1] : GCAATTGGGGA--CTGGGGTCCTATAґATACTAGAA-CCCTCTATAGAACTTTC ToCMoV-[MG-Bt1] : GCAATTGGGGA--CTGGGGTCCTATAPATACTAGAA-CCCTCTATAGAACTTTC SimMV-[A2B2] : TGAATTGGGGT-AATGGGGA CAATAPATAGTAGAA--GATCCTAAGGG----SiYMV

BGMV

TOCrLYV-B

SimMV- [A1B3]

SiMV

NDNV

: TGAACTGGGGA--CTGGGGTCTTATTIATAGCAGA----CTCCATATAATTTTT

: TGAATCGGTG-TAATGGTG-CCAATAPATAGTAAGA-AGTTCTTTAAGGATCTG

: TCAATTGGTG--ACTGGTGTACAATAPATAGTAGAA-GCCTCTATAGAACTCTC

: GAA-TTGGAG--TATGGAGTACAATAPATATGAGGA---GTTCCTAGAG----T

GAAATTGGAG--TATGGAGTACAATAPATAGTAGGA---GTTCCTAAGG----G

: TGTATTGGAG--ACTAGAGC-CAATAPATAGTAGAGAAGTTCTCTAGGACCTTG

TGMV

TGAATTGGTAGTA AGgTAGCTCTTAPATAITAGAA--GTTCCT--AAGGGG--

TORMV

TGAATTGGTAGTTATGGTAGCTCTTAPATACTAGAA--GTTCCTTTAAGGAGAT

TOSRV

TGAATTGGTAGTAATGGTAGCTCTTAEATAGTAGAA--GTTCCTTTAAGGAGAT

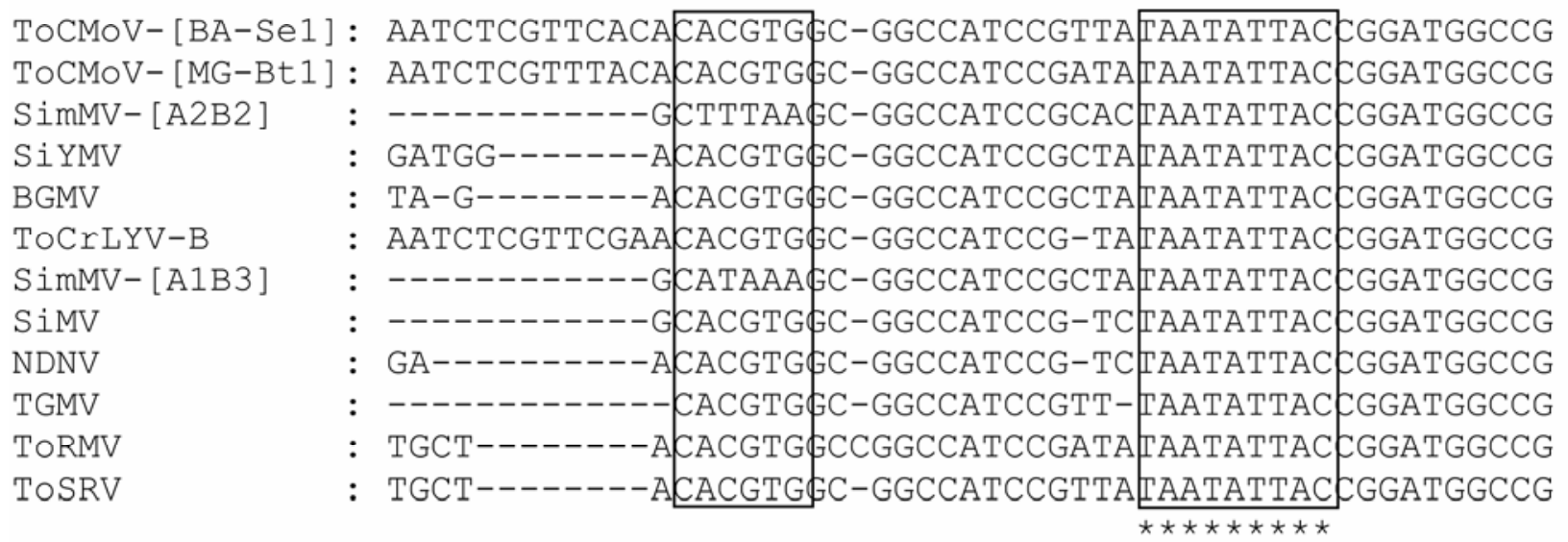

Fig. 2. Multiple alignment of the common regions of a selection of Brazilian begomoviruses. The TATA box, G-box, and conserved nanonucleotide are boxed. Iterated direct repeats (iterons) are in light gray; inverted repeats are in dark gray. The arrows indicate the direction of the repeat. GGGGT in TYLCrV and GGGGC sequences in Tomato golden mosaic virus-[Yellow vein] (TGMV-[YV]) are underlined. All sequences are derived from the A component, except for Tomato crinkle leaf yellow virus (ToCrLYV). 
Bt1], SiYMV, and SimMV-[A2B2] have the same GGGGA iteron. However, instead of a third direct repeat, SimMV-[A2B2] has an inverted repeat. The sequence identity of these elements suggests that reassortment among components of these viruses might be possible. It is interesting to point out that, although the iteron sequences for ToCrLYV and TGMV-[YV] are GGTG and GGTAG, respectively, both viruses also have a GGGGT (GGGGC for TGMV) DNA-A sequence upstream of their $5^{\prime}$ iteron (Fig. 2) which might facilitate the interaction of genome components of these two viruses with the Reps of viruses possessing GGGGA iteron sequences.

Although the frequency of component reassortment in nature is unknown, experimental reassortment can sometimes yield viable pseudorecombinants $(18,38)$. For example, Galvao et al. (16) obtained viable pseudorecombinants between the Brazilian begomoviruses ToCMoV-[MG-Bt1] DNA-A and ToCrLYV DNA-B despite these viruses having different iteron sequences. Although ToCMoV-[MG-Bt1] DNA-A (with GGGGA iterons) and ToCrLYV DNA-B (with GGTG iterons) could systemically infect $N$. benthamiana and tomato, in tomato no symptoms developed. To determine whether viable reassortments between ToCMoV-[BASe1] and ToRMV were possible, cognate and reassorted components were introduced into $N$. benthamiana seedlings by particle bombardment. Although high infection rates were obtained with cognate ToCMoV-[BA-Se1] components (15 of 17 inoculated plants) and ToRMV components (10 of 14 plants), none of the reassortants between these viruses were viable, as evidenced by the absence of both symptoms and detectable viral DNA in inoculated plants.

Recombination. In an analysis of recombination between New World begomovirus DNA-A components, we detected significant evidence of 49 unique events involving either of the two ToCMoV isolates as potential donors or acceptors of sequence. However, in most cases, it was very difficult to discern whether the ToCMoV isolates were donors or acceptors of sequence during these events. Each detected recombination event split the alignment into two fractions, each corresponding to the portions of sequence derived from either of two parental viruses. We called the portion of the alignment corresponding to the larger fraction the major region and the fraction of sequence corresponding to the smaller fraction the minor region. Starting with the most obvious recombination events (those yielding the lowest $P$ value scores), we progressively examined every event, constructing two bootstrapped (1,000 replicates) neighbor-joining trees for the major and minor regions indicated by each event. From these trees, the minimum number of tree modifications (branch cutting and grafting) required to convert each tree into the other was determined using a method similar to that described by McLeod et al. (33). Given both the minimum number of cuts and grafts required to convert each tree into the other, and the 49 sets of potential parental and
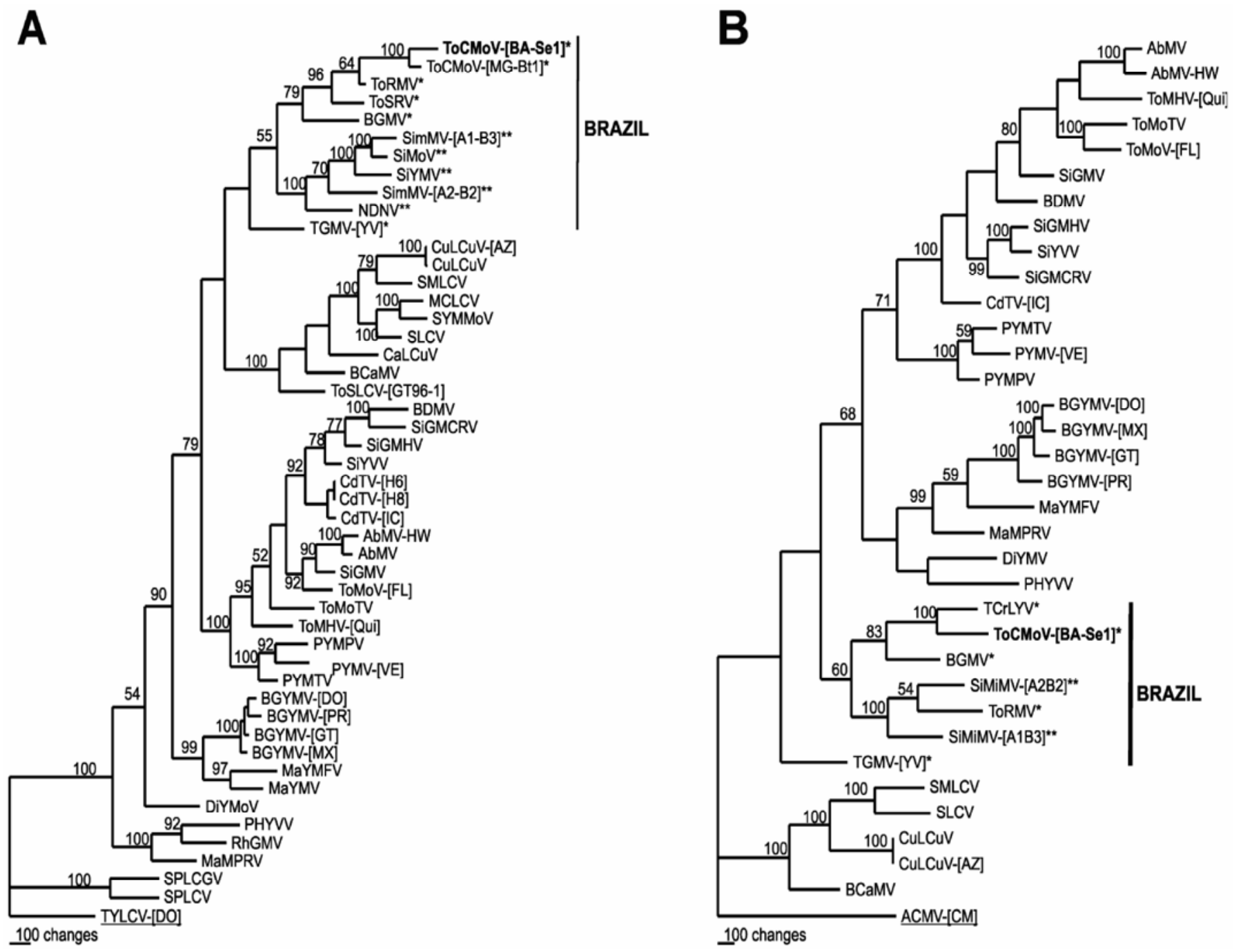

Fig. 3. Phylogenetic trees illustrating predicted relationships among A, Tomato chlorotic mottle virus (ToCMoV-[BA-Se1] DNA-A and B, ToCMoV-[BA-Se1] DNA-B sequences with those of other New World begomoviruses. Trees were constructed using maximum parsimony after bootstrapping for 1,000 replicates. Bootstrap values greater than $50 \%$ are indicated at the nodes. Acronyms and accession numbers are supplied in the text. Brazilian crop-infecting viruses are indicated by one asterisk and weed-infecting viruses by two asterisks. Viruses used as outgroups are underlined. 
recombinant sequences identified for the different recombination events, in 34 cases we inferred that the sequences that moved during pruning and grafting were recombinants. In the 15 remaining cases, however, pruning and grafting also involved moving either one or both parents. This probably indicated that the parental viruses used to detect the events were themselves recombinants. In such cases, we used the Phylpro method (52) to choose the most likely recombinant from among the two or three sequences that the pruning and grafting method had indicated were possible recombinants. The Phylpro method examines the pairwise Jukes-Cantor distances between a potential recombinant and all the other sequences in the alignment, and linearly regresses the distances determined for the major region of the alignment against those determined for the minor region. The comparison yielding the lowest correlation coefficient indicates which of the sequences is more likely to be recombinant.

Of the 49 events involving the ToCMoV isolates as either donor or acceptor sequences, we identified only four events in which it is very likely that the $\mathrm{ToCMoV}$ isolates were sequence acceptors (Fig. 4, events a-d). Although both isolates bear evidence of all four events, event c was detectable only by the use of more than one recombination detection method in ToCMoV-[BA-Se1]. Because all of these events are detectable in both sequences, it is likely that they occurred before the isolates diverged and, therefore, are reasonably old events. Interestingly, the results of our recombination analysis contradict that of a previous study (16), which indicated that ToCMoV-[MG-Bt1] could be a ToCMoV[BA-Se1]-ToRMV recombinant. Because both the prune-graft and Phylpro (52) methods indicate that ToRMV is an acceptor sequence, we propose here that it is, in fact, ToRMV that is a ToCMoV-[MG-Bt1]-ToSRV recombinant (Fig. 4, event e). ToRMV is more closely related to ToCMoV-[MG-Bt1] between genome positions 1 and 1,700 than it is to ToCMoV-[BA-Se1], implying that this recombination event is reasonably recent and occurred after MG-Bt1 and BA-Se1 diverged. Accordingly, ToRMV also bears evidence of three of the more ancient recombination events detected in this region in the ToCMoV isolates.

No evidence of recombination was detected in the DNA-B sequences of ToCMoV-[BA-Se1].

\section{DISCUSSION}

We have undertaken a molecular and biological characterization of a new Begomovirus sp. involved in tomato disease outbreaks in northeastern Brazil. It is the first identified begomovirus specie from this region of South America (39) and, although related viruses have been partially characterized elsewhere, this study is the first to report the full sequence of cloned genome components capable of inducing symptomatic infections in tomato that are indistinguishable from those seen in the field.

We have demonstrated that cloned ToCMoV-[BA-Se1] was both whitefly transmissible and infectious using different methods of artificial inoculation. The molecular and biological characteristics of the two genome components were those of a typical bipartite begomovirus specie, with infection achievable only when both components were inoculated into a susceptible plant.

The high degree of DNA-A sequence identity shared by ToCMoV-[BA-Se1] and ToCMoV-[MG-Bt1] is surprising, in that these two viruses apparently have different infection capabilities. ToCMoV-[MG-Bt1] DNA-A can systemically infect and induce symptoms in $N$. benthamiana in the absence of DNA-B (16). Despite several attempts to infect $N$. benthamiana and tomato with ToCMoV-[BA-Se1] DNA-A on its own, neither symptomatic nor asymptomatic systemic infections were achievable in these hosts in the absence of DNA-B. The biological significance in nature of ToCMoV-[MG-Bt1] DNA-A being able to symptomatically infect $N$. benthamiana without DNA-B is unknown. The DNA-A components of other, usually bipartite, viruses such as ACMV, AbMV, ToMoV, BDMV, Sri Lankan cassava mosaic virus, Tomato leaf curl Thailand virus, and Tomato leaf curl Guajarat virus-[Var], also have the capacity to infect $N$. benthamiana in the absence of DNA-B $(6,8,16,21,23,39,42,48)$. However, the symptoms induced in these exclusively DNA-A infections are invariably milder than the symptoms induced when DNA-A components are co-inoculated with their cognate DNA-B components. Moreover, all of these viruses, including ToCMoV, always are found accompanied by a cognate DNA-B in nature. In addition to improving the capacity of bipartite viruses to move within and between infected cells $(21,50)$, a DNA-B component may increase the whitefly transmissibility of viruses (27). In a natural setting, either new opportunities (such as that provided by a more promiscuous vector biotype) or environmental pressures to infect new host species also may favor the maintenance of DNA-B.

Host range information is an important prerequisite for understanding the epidemiology of viruses and also can be useful for their characterization and effective management (37). The experimental host range of ToCMoV-[BA-Se1] includes agricultural, ornamental, and weed species commonly found in the northeastern parts of Brazil where the virus was isolated. Our data implies both that $\mathrm{ToCMoV}$ can infect and become a problem in crops like tobacco, soybean, and pepper, and that these crops, along with weed species such as Nicandra physaloides, might provide an inoculum source for the infection of tomato crops. We

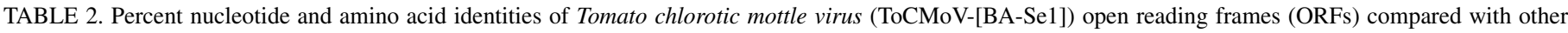
Brazilian begomoviruses

\begin{tabular}{|c|c|c|c|c|c|c|c|c|c|c|c|}
\hline \multirow[b]{2}{*}{ Virus $^{b}$} & \multirow[b]{2}{*}{ A } & \multirow[b]{2}{*}{$\mathrm{B}$} & \multirow[b]{2}{*}{$\mathrm{CR}^{\mathrm{c}}$} & \multicolumn{8}{|c|}{ Individual ORFs $^{\mathrm{a}}$} \\
\hline & & & & AV1 & $\mathrm{AC} 1$ & $\mathrm{AC} 2$ & $\mathrm{AC} 3$ & $\mathrm{AC} 4$ & $\mathrm{AC} 5$ & BV1 & $\mathrm{BC} 1$ \\
\hline ToCMoV-[MG-Bt1] & 92 & NA & 95 & $91 / 96$ & $93 / 93$ & $95 / 90$ & $94 / 94$ & $95 / 86$ & $90 / 76$ & NA & NA \\
\hline ToRMV & 84 & 63 & 75 & $92 / 99$ & $77 / 80$ & $95 / 91$ & $94 / 94$ & $71 / 43$ & $92 / 80$ & $71 / 67$ & $73 / 78$ \\
\hline ToSRV & 78 & NA & 76 & $82 / 90$ & $75 / 75$ & $82 / 75$ & $85 / 81$ & $70 / 43$ & $84 / 62$ & NA & NA \\
\hline TGMV-[YV] & 76 & 62 & 71 & $82 / 88$ & $74 / 74$ & $79 / 70$ & $83 / 78$ & $73 / 54$ & $81 / 52$ & $70 / 66$ & $76 / 84$ \\
\hline BGMV-[BR] & 76 & 62 & 71 & $83 / 92$ & $73 / 72$ & $84 / 76$ & $83 / 81$ & $67 / 32$ & $84 / 59$ & $70 / 71$ & $73 / 78$ \\
\hline NDNV & 75 & NA & 66 & $84 / 91$ & $72 / 71$ & $83 / 76$ & $83 / 80$ & $63 / 30$ & $90 / 76$ & NA & NA \\
\hline SiMoV & 75 & NA & 73 & $84 / 91$ & $72 / 64$ & $81 / 69$ & $82 / 78$ & $77 / 53$ & $87 / 70$ & NA & NA \\
\hline SiYMV & 78 & NA & 78 & $83 / 84$ & $78 / 76$ & $80 / 59$ & $83 / 64$ & $86 / 71$ & $87 / 64$ & NA & NA \\
\hline SimMV-(A1B3) & 75 & 63 & 68 & $83 / 91$ & $73 / 71$ & $78 / 72$ & $82 / 77$ & $69 / 42$ & $88 / 70$ & $71 / 71$ & $72 / 80$ \\
\hline SimMV-(A2B2) & 75 & 62 & 72 & $83 / 90$ & $70 / 72$ & $82 / 65$ & $83 / 81$ & $73 / 47$ & $88 / 70$ & $70 / 70$ & $71 / 78$ \\
\hline ToCrLYV & NA & 76 & 81 & NA & NA & NA & NA & NA & NA & $81 / 81$ & $86 / 91$ \\
\hline
\end{tabular}

a Nucleotide sequence/deduced amino acid sequence identities; NA = not available.

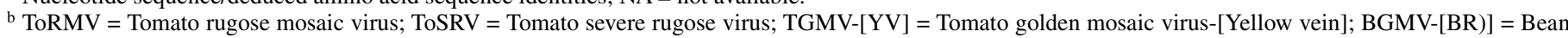
golden mosaic virus-[Brazil]; NDNV = Nicandra deforming necrosis virus; SiMoV = Sida mottle virus; SiYMV = Sida yellow mosaic virus; SimMV = Sida micrantha mosaic virus; and ToCrLYV = Tomato crinkle leaf yellow virus.

c Common region (CR) sequence is from the A component, except for ToCrLYV. 
previously have detected begomovirus-infected pepper plants in the state of Pernambuco (26) at the same time and area in which other ToCMoV variants were detected from tomato (39). Although the exact identity of this pepper-infecting begomovirus specie is unknown, the ability of ToCMoV-[BA-Se1] to infect all of the pepper genotypes tested indicates that the virus is a potential threat to pepper cultivation.

ToCMoV and other emerging tomato-infecting begomovirus species are apparently indigenous Brazilian viruses that, probably due to the broad host preference of the newly introduced $B$ biotype of $B$. tabaci $(4,28)$, recently have become transmissible to tomato. $N$. physaloides is a common weed found in tomato fields. Even though ToCMoV-[BA-Se1] experimentally infected this host and induced symptoms similar to those induced by NDNV, a begomovirus specie isolated from this host (A. K. Inoue-Nagata and S. G. Ribeiro, unpublished data), ToCMoV-[BA-Se1], and NDNV share only $75 \%$ sequence identity. Whereas alternative natural hosts have been identified for ToRMV $(13,22)$ and Tomato yellow vein streak virus (ToYVSV) (41), recent surveys have failed thus far to detect $\mathrm{ToCMoV}$ in any host other than tomato (1). One possible reason for this is that sampling generally has focused on the collection of symptomatic plants. We have shown here that, as is the case with other Brazilian tomato begomoviruses $(13,47)$, ToCMoV-[BA-Se1] is capable of asymptomatically infecting different host species. A case for the importance of asymptomatic infections in the spread of begomoviruses has been made with TYLCV-[DO]. This virus asymptomatically infects several weed species in the Dominican Republic and it has been demonstrated that viruses transmitted from these weeds play an important role in the primary infection of tomato plants early in the season (46). Surveys of asymptomatic weed plants within the vicinity of infected tomato fields might indicate whether or not a similar situation is occurring with ToCMoV and other Brazilian tomato begomoviruses.

Phylogenetic analyses based on New World begomovirus DNA-A sequences supports recently published results (43) indicating that Brazilian begomoviruses form a distinct monophyletic group. Within this group the viruses apparently are segregated into crop- and weed-infecting clades, although additional sampling may blur this distinction. ToCMoV-[BA-Se1] clusters together with ToCMoV-[MG-Bt1] within the crop-infecting group, indicating that both virus isolates, despite being isolated $>1,000 \mathrm{~km}$ apart, belong to the same new species.

Pseudorecombination and recombination are apparently common features of begomovirus evolution $(20,35,45)$ and might contribute to the emergence of novel, highly pathogenic virus variants such as the one causing severe cassava mosaic disease in Uganda (36). Although experimental reassortment between components of Brazilian begomoviruses has been demonstrated (16), we have found here that ToCMoV-[BA-Se1] and the closely related virus, ToRMV, do not form viable pseudorecombinants. This probably is due to the high degree of divergence in both their iteron and Rep-binding domain sequences.

Our recombination analysis indicates a possible reason for ToRMV having an apparently incongruent B-component. Whereas ToRMV and ToCMoV isolates are very similar from their origins of virion strand replication to the end of their AC1 ORFs, most of the ToRMV AC1 and the common region containing the iteron sequences and Rep-binding domain have been
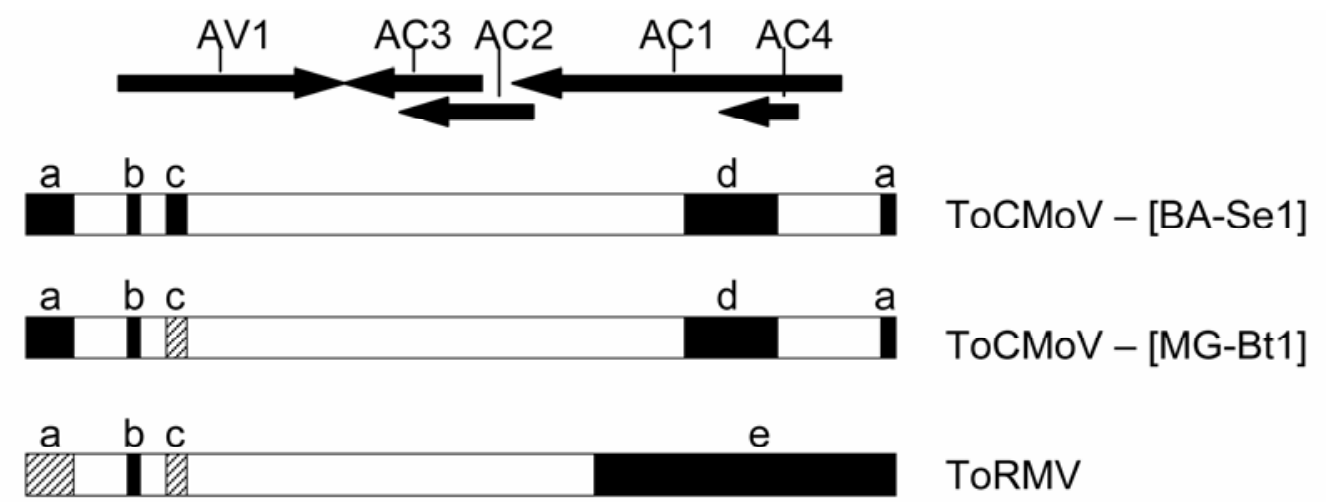

e

ToRMV

\begin{tabular}{|c|c|c|c|c|c|c|c|c|c|c|}
\hline \multirow[b]{2}{*}{ Region } & \multicolumn{2}{|c|}{ Breakpoints } & \multicolumn{2}{|c|}{ Parents $^{a}$} & \multicolumn{6}{|c|}{ Detection Method } \\
\hline & Begin & End & Major & Minor & RDP & GENECONV & BOOTSCAN & MAXCHI & CHIMAERA & SISCAN \\
\hline a & 2578 & 93 & $\mathrm{BGMV}-[\mathrm{BR}]^{b}$ & ToMoV-[FL $]^{b}$ & $7.89 \times 10^{-7}$ & $2.02 \times 10^{-4}$ & $2.80 \times 10^{-5}$ & $8.76 \times 10^{-3}$ & $N^{c}$ & NS \\
\hline b & 232 & 272 & ToSRV & Unknown ${ }^{d}$ & $2.25 \times 10^{-5}$ & $8.80 \times 10^{-3}$ & NS & $1.32 \times 10^{-3}$ & $5.27 \times 10^{-3}$ & $2.29 \times 10^{-11}$ \\
\hline c & 361 & 424 & BGMV-[BR] $]^{b}$ & MaMPRV $^{b}$ & $5.47 \times 10^{-3}$ & NS & NS & NS & NS & $3.53 \times 10^{-4}$ \\
\hline d & 1973 & 2283 & BGMV-[BR] ${ }^{b}$ & PYMPV $^{b}$ & $1.34 \times 10^{-6}$ & $2.97 \times 10^{-2}$ & $2.14 \times 10^{-5}$ & $3.40 \times 10^{-8}$ & $1.56 \times 10^{-7}$ & $8.20 \times 10^{-2}$ \\
\hline $\mathrm{e}$ & 1701 & 2932 & ToCMoV-[MG-Bt1 & 1] ToSRV & $5.36 \times 10^{-52}$ & $2.33 \times 10^{-45}$ & $9.29 \times 10^{-60}$ & $6.28 \times 10^{-33}$ & $2.50 \times 10^{-16}$ & $1.70 \times 10^{-8}$ \\
\hline
\end{tabular}

\footnotetext{
${ }^{a}$ The major parent contributed most of the recombinant's sequence and the minor parent contributed the smaller fraction of sequence.

${ }^{b}$ Identified parent is only a distant relative of the actual parent.

${ }^{c} \mathrm{NS}=$ No significant $\mathrm{P}$ value $(\mathrm{P}>0.1)$ obtained with this test.

${ }^{d}$ Given adequate sampling, a recombinant sequence can be detected even if only one of the parental sequences has been sampled.
}

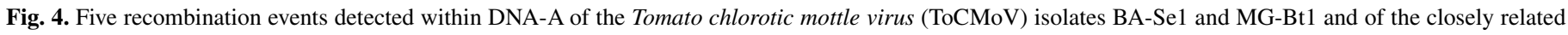

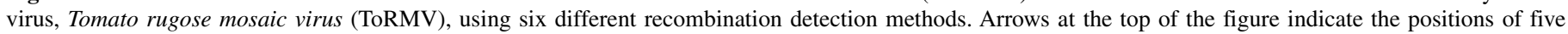

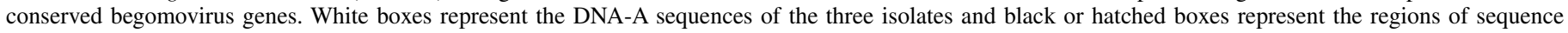

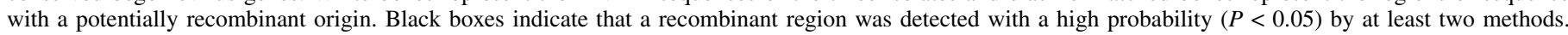

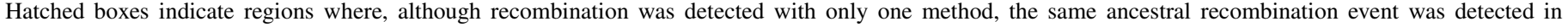

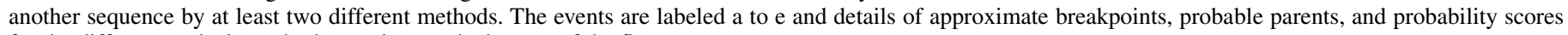
for the different analysis methods are given at the bottom of the figure. 
derived from a sequence resembling ToSRV. It is probable that, following a relatively recent ToSRV-ToCMoV recombination event, the nascent ToRMV selected the ToSRV B-component with which it shared appropriate iteron and Rep-binding sequences. Properly testing this hypothesis would first require the isolation of, and pseudorecombination studies with, a ToSRV DNA-B sequence.

Our recombination analysis also suggests that $\mathrm{ToCMoV}$ has a long history of recombination. Four recombination events were detected within the DNA-A sequences of the ToCMoV isolates BA-Se1 and MG-Bt1. Although only distant relatives of the actual parental viruses involved in these events were identified, further sampling and characterization of both crop- and weed-infecting begomoviruses might lead to the identification of a virus more closely resembling ToCMoV's parents. Whereas ToRMV is apparently the product of a quite recent ToCMoV-ToSRV recombination event, the four events detected in ToCMoV (three of which are also identifiable in ToRMV) are considerably older and precede the divergence of ToCMoV isolates BA-Se1 and MGBt1. Therefore, whereas recombination may have contributed to the recent emergence of ToRMV, it is unlikely that it has contributed to the emergence of ToCMoV.

Of the new begomoviruses believed to be involved in Brazilian tomato disease epidemics $(10,39)$, ToCMoV, ToRMV, ToSRV, and ToYVSV seem to have expanded their initial geographic ranges in the last 5 years. ToCMoV recently was detected in central Brazil infecting tomato plants in the Federal District (5) and in Paty dos Alferes, RJ (14), the largest fresh market tomato-producing area in the country. Interestingly, tomato plants in the latter area were begomovirus free until 2004. In both cases, ToCMoV was found in mixed infections with at least one other begomovirus specie, and novel recombinants were detected. Although it seems that these four species currently are dominating the begomovirus epidemic in tomato, it appears that the situation is far from static. Although inbred or transgenic resistance in tomato is going to be difficult enough to achieve against all these viruses, there is a perpetual risk that resistance-breaking or ultrapathogenic recombinant variants, and possibly even new species, could emerge at any time.

\section{ACKNOWLEDGMENTS}

D. P. Martin was funded by the South African National Bioinformatics Network, and C. Lacorte received a CAPES scholarship. We thank M. F. Lima for collecting samples; E. A. Gomes for assistance in automated sequencing; F. Murilo Zerbini for providing ToRMV infectious clones and for helpful discussions; and M. Prins and R. Goldbach for critical review of the manuscript.

\section{LITERATURE CITED}

1. Ambrozevícius, L. P., Calegario, R. F., Fontes, E. P. B., Carvalho, M. G., and Zerbini, F. M. 2002. Genetic diversity of begomovirus infecting tomato and associated weeds in southeastern Brazil. Fitopatol. Bras. 27:372-377.

2. Aragão, F. J. L., Brasileiro, A. C. M., Ribeiro, S. G., Faria, J. C., and Rech, E. L. 1995. Inoculation of bean and soybean with cloned Bean golden mosaic virus (BGMV) DNA using particle acceleration. Fitopatol. Bras. 20:642-644.

3. Arguello-Astorga, G., Herrera-Estrella, L., and Rivera-Bustamante, R. F. 1994. Experimental and theoretical definition of geminivirus origin of replication. Plant Mol. Biol. 26:553-556.

4. Bedford, I. D., Briddon, R. W., Brown, J. K., Rosell, R. C., and Markham, P. G. 1994. Geminivirus transmission and biological characterisation of Bemisia tabaci (Gennadius) biotypes from different geographic regions. Ann. Appl. Biol. 125:311-325.

5. Carrijo, F. R. F., Albuquerque, L. C., Ávila, A. C., Giordano, L. B., Boiteux, L. S., and Inoue-Nagata, A. K. 2005. Incidence of begomovirus in tomato for processing and for fresh market in 2004. Fitopatol. Bras. 30:S187.

6. Chakraborty, S., Pandey, P. K., Banerjee, M. K., Kalloo, G., and Fauquet,
C. M. 2003. Tomato leaf curl Gujarat virus, a new Begomovirus species causing a severe leaf curl disease of tomato in Varanasi, India. Phytopathology 93:1485-1495.

7. Dellaporta, S. L., Wood, J., and Hicks, J. B. 1983. A plant DNA minipreparation: version II. Plant Mol. Biol. Rep. 1:19-21.

8. Evans, D., and Jeske, H. 1993. DNA B facilitates, but is not essential for, the spread of abutilon mosaic virus in agroinoculated Nicotiana benthamiana. Virology 194:752-757.

9. Faria, J. C., Bezerra, I. C., Zerbini, F. M., Ribeiro, S. G., and Lima, M. F. 2000. Situação atual das geminiviroses no Brasil. Fitopatol. Bras. 25:125137.

10. Faria, J. C., Souza Dias, J. A. C., and Slack, S. A. 1997. A new geminivirus associated with tomato in the state of São Paulo, Brazil. Plant Dis. 81:423.

11. Fauquet, C. M., Bisaro, D. M., Briddon, R. W., Brown, J. K., Harrison, B. D., Rybicki, E. P., Stenger, D. C., and Stanley, J. 2003. Revision of taxonomic criteria for species demarcation in the family Geminiviridae, and an updated list of Begomovirus species. Arch. Virol. 148:405-421.

12. Fauquet, C. M., and Stanley, J. 2003. Geminivirus classification and nomenclature: progress and problems. Ann. Appl. Biol. 142:165-189.

13. Fernandes, J. J. 2002. Identificação e Caracterização Biologica e Molecular de Begomovirus Infectando Tomateiro na Região de Triangulo Mineiro, MG. Tese de Doutorado, UFV, Viçosa.

14. Ferreira, S. S., Alfenas, P. F., Lima, A. T. M., Barros, D. R., Senna, L., and Zerbini, F. M. 2005. Detection of begomoviruses infecting tomatoes at Paty de Alferes, Rio de Janeiro. Fitopatol. Bras. 30:S183.

15. Fontes, E. P. B., Eagle, P. A., Sipe, P. S., Lucknow, V. A., and HanleyBowdoin, L. 1994. Interaction between a geminivirus replication protein and origin DNA is essential for viral replication. J. Biol. Chem. 269:84598465.

16. Galvão, R. M., Mariano, A. C., Luz, D. F., Alfenas, P. F., Andrade, E. C., Zerbini, F. M., Almeida, M. R., and Fontes, E. P. B. 2003. A naturally occurring recombinant DNA-A of a typical bipartite begomovirus does not require the cognate DNA-B to infect Nicotiana benthamiana systemically. J. Gen. Virol. 84:715-726.

17. Gibbs, M. J., Armstrong, J. S., and Gibbs, A. J. 2000. Sister-Scanning: a Monte Carlo procedure for assessing signals in recombinant sequences. Bioinformatics 16:573-582.

18. Gilbertson, R. L., Hidayat, S. H., Paplomatas, E. J., Rojas, M. R., Hou, Y. M., and Maxwell, D. P. 1993. Pseudorecombination between infectious cloned DNA components of tomato mottle and bean dwarf mosaic geminiviruses. J. Gen. Virol. 74:23-31.

19. Hanley-Bowdoin, L., Settlage, S. B., Orozco, B. M., Nagar, S., and Robertson, D. 1999. Geminiviruses: models for plant DNA replication, transcription, and cell cycle regulation. Crit. Rev. Plant Sci. 18:71-106.

20. Harrison, B. D., and Robinson, D. J. 1999. Natural genomic and antigenic variation in whitefly-transmitted geminiviruses (begomoviruses). Annu. Rev. Phytopathol. 37:369-398.

21. Hou, Y.-M., Paplomatas, E. J., and Gilbertson, R. L. 1998. Host adaptation and replication properties of two bipartite geminiviruses and their pseudorecombinants. Mol. Plant-Microbe Interact. 11:207217.

22. Jovel, J., Reski, G., Rothenstein, D., Ringel, M., Frischmuth, T., and Jeske, H. 2004. Sida micrantha mosaic is associated with a complex infection of begomoviruses different from Abutilon mosaic virus. Arch. Virol. 149:829-841.

23. Klinkenberg, F. A., and Stanley, J. 1990. Encapsidation and spread of African cassava mosaic virus DNA A in the absence of DNA B when agroinoculated to Nicotiana benthamiana. J. Gen. Virol. 71:14091412.

24. Laufs, J., Traut, W., Heyraud, F., Matzeit, V., Rogers, S. G., Schell, J., and Gronenborn, B. 1995. In vitro cleavage and joining at the viral origin of replication by the replication initiator protein of Tomato yellow leaf curl virus. Proc. Natl. Acad. Sci. USA 92:3879-3883.

25. Lazarowitz, S. G. 1992. Geminiviruses: genome structure and gene function. Crit. Rev. Plant Sci. 11:327-349.

26. Lima, M. F., Bezerra, I. C., Ribeiro, S. G., and Avila, A. C. 2001 Distribution of geminivirus in tomato and sweet pepper crops in twelve counties of the Lower basin of San Francisco Valley. Fitopatol. Bras. 26:81-85.

27. Liu, S., Bedford, I. D., Briddon, R. W., and Markham, P. G. 1997. Efficient whitefly transmission of African cassava mosaic geminivirus requires sequences from both genomic components. J. Gen. Virol. 78:1791-1794

28. Lourenção, A. L., and Nagai, H. 1994. Surtos populacionais de Bemisia tabaci no estado de São Paulo. Bragantia 53:53-59.

29. Martin, D. P., Posada, D., Crandall, K. A., and Williamson, C. A. 2005. A modified bootscan algorithm for automated identification of recombinant sequence and recombination breakpoints. AIDS Res. Hum. Retrovir. 21:98-102. 
30. Martin, D. P., and Rybicki, E. P. 2000. RDP: detection of recombination amongst aligned sequences. Bioinformatics 15:562-563.

31. Martin, D. P., Williamson, C. A., and Posada, D. 2005. RDP2: Recombination detection and analysis from sequence alignments. Bioinformatics 21:260-262.

32. Maynard Smith, J. 1992. Analysing the mosaic structure of genes. J. Mol. Evol. 34:126-129.

33. McLeod, D., Charlebois, R. L., Doolittle, F., and Bapteste, E. 2005. Deduction of probable events of lateral gene transfer through comparison of phylogenetic trees by recursive consolidation and rearrangement. BMC Evol. Biol. 5:27.

34. Morales, F. J., and Anderson, P. K. 2001. The emergence and dissemination of whitefly-transmitted geminiviruses in Latin America. Arch. Virol. 146:415-441.

35. Padidam, M., Sawyer, S., and Fauquet, C. M. 1999. Possible emergence of new geminiviruses by frequent recombination. Virology 265:218-225.

36. Pita, J. S., Fondong, V. N., Sangare, A., Otim Nape, G. W., Ogwal, S., and Fauquet, C. M. 2001. Recombination, pseudorecombination and synergism of geminiviruses are determinant keys to the epidemic of severe cassava mosaic disease in Uganda. J. Gen. Virol. 82:655-665.

37. Polston, J. E., and Anderson, P. K. 1997. The emergence of whiteflytransmitted geminiviruses in tomato in the Western Hemisphere. Plant Dis. $81: 1358-1369$.

38. Ramos, P. L., Guevara-Gonzalez, R. G., Peral, R., Ascencio-Ibanez, J. T., Polston, J. E., Arguello-Astorga, G. R., Vega-Arreguin, J. C., and RiveraBustamante, R. F. 2003. Tomato mottle Taino virus pseudorecombines with PYMV but not with ToMoV: implications for the delimitation of cisand trans-acting replication specificity determinants. Arch. Virol. 148:1697-1712.

39. Ribeiro, S. G., Ambrozevícius, L. P., De Avila, A. C., Bezerra, I. C., Calegario, R. F., Fernandes, J. J., Lima, M. F., Mello, R. N., Rocha, H., and Zerbini, F. M. 2003. Distribution and genetic diversity of tomatoinfecting geminiviruses in Brazil. Arch. Virol. 148:281-295.

40. Ribeiro, S. G., De Avila, A. C., Bezerra, I. C., Fernandes, J. J., Faria, J. C., Lima, M. F., Gilbertson, R. L., Maciel Zambolim, E., and Zerbini, F. M. 1998. Widespread occurrence of tomato geminiviruses in Brazil, associated with the new biotype of the whitefly vector. Plant Dis. 82:830.

41. Ribeiro, S. G., Inoue-Nagata, A. K., Daniels, J., and Avila, A. C. 2006. Potato deforming mosaic disease is caused by an isolate of Tomato yellow vein streak virus. Plant Pathol. 55:569.
42. Rochester, D. E., Kositratana, W., and Beachy, R. N. 1990. Systemic movement and symptom production following agroinoculation with a single DNA of tomato yellow leaf curl geminivirus Thailand. Virology 178:520-526.

43. Rojas, A., Kvarnheden, A., Marcenaro, D., and Valkonen, J. P. T. 2005. Sequence characterization of Tomato leaf curl Sinaloa virus and Tomato severe leaf curl virus: phylogeny of New World begomovirus and detection of recombination. Arch. Virol. 150:1281-1299.

44. Rojas, M. R., Gilbertson, R. L., Russell, D. R., and Maxwell, D. P. 1993. Use of degenerate primers in the polymerase chain reaction to detect whitefly-transmitted geminiviruses. Plant Dis. 77:340-347.

45. Rojas, M. R., Hagen, C., Lucas, W. J., and Gilbertson, R. L. 2005. Exploiting chinks in the plant's armor: evolution and emergence of geminiviruses. Annu. Rev. Phytopathol. 43:361-394.

46. Salati, R., Nahkla, M. K., Rojas, M. R., Guzman, P., Jaquez, J., Maxwell, D. P., and Gilbertson, R. L. 2002. Tomato yellow leaf curl virus in the Dominican Republic: characterization of an infectious clone, virus monitoring in whiteflies, and identification of reservoir hosts. Phytopathology 92:487-496.

47. Santos, C. D., Avila, A. C., Inoue Nagata, A. K., and Resende, R. O. 2004. Espécies vegetais hospedeiras de begomovírus isolados de tomateiro em Goiás e no Distrito Federal. Fitopatol. Bras. 29:450-455.

48. Saunders, K., Salim, N., Mali, V. R., Malathi, V. G., Briddon, R., Markham, P. G., and Stanley, J. 2002. Characterisation of Sri Lankan cassava mosaic virus and Indian cassava mosaic virus: evidence for acquisition of a DNA B component by a monopartite begomovirus. Virology 293:63-74.

49. Thompson, J. D., Gibson, T. J., Plewniak, F., Jeanmougin, F., and Higgins, D. G. 1997. The ClustalX windows interface: flexible strategies for multiple sequence alignment aided by quality analysis tools. Nucleic Acids Res. 25:4876-4882.

50. Unseld, S., Ringel, M., Hoefer, P., Hoehnle, M., Jeske, H., Bedford, I. D., Markham, P. G., and Frischmuth, T. 2000. Host range and symptom variation of pseudorecombinant virus produced by two distinct bipartite geminiviruses. Arch. Virol. 145:1449-1454.

51. Varma, A., and Malathi, V. G. 2003. Emerging geminivirus problems: a serious threat to crop production. Ann. Appl. Biol. 142:145-164.

52. Weiller, G. F. 1998. Phylogenetic profiles: a graphical method for detecting genetic recombinations in homologous sequences. Mol. Biol. Evol. 15:326-335. 